\title{
TEACHING HISTORY AND CIVIC EDUCATION IN SLOVENIA
}

\author{
La enseñanza de la historia y la educación cívica en Eslovenia
}

\author{
Danijela Trškan \\ danijela.trskan@ff.uni-lj.si \\ University of Ljubljana. Slovenia \\ Špela Bezjak \\ spela.bezjak@ff.uni-lj.si \\ University of Ljubljana. Slovenia
}

Fecha de recepción: 29/03/2021

Fecha de aceptación: 20/04/2021

SUMMARY: The article explains how civic education is included in the subject of history in elementary and secondary schools in Slovenia. History is a compulsory subject taught in elementary and secondary schools and plays an important role in the cultural, social and political education of young people - young citizens. The analysis of current history curricula indicates that they contain civic and patriotic elements in the general and specific objectives and learning outcomes, as well as in the content. The analysis of selected history textbooks shows that Slovenian textbooks include more European history than Slovenian history. The article explains what social and civic competences can be developed and fostered in the subject of history and how elementary and secondary school students can use various examples from the past to develop a positive attitude towards Slovenian identity and the protection of Slovenian cultural heritage, a respectful attitude towards human rights and democratic citizenship, towards different cultures, religions and nations, and responsible sociopolitical activity. It has been noted that history teachers have many opportunities to teach students the relevant values of democratic citizenship and to enable them to know and understand themselves as individuals and as members of the local and global communities. However, more attention should be paid to contemporary Slovenian history and active citizenship.

Keywords: history; civic education; curriculum; elementary school; secondary school; Slovenia. 
RESUMEN: El artículo explica cómo se incluye la educación cívica en la asignatura de historia en las escuelas primarias y secundarias de Eslovenia. La historia es una asignatura obligatoria que se imparte en las escuelas primarias y secundarias y desempeña un papel importante en la educación cultural, social y política de los jóvenes - los jóvenes ciudadanos. Un análisis de los actuales planes de estudio de historia muestra que contienen elementos cívicos y patrióticos en los objetivos generales y específicos y en los resultados del aprendizaje, así como en el contenido. Un análisis de los libros de texto de historia seleccionados muestra que los libros de texto eslovenos incluyen más historia europea que eslovena. EI artículo explica qué competencias sociales y cívicas pueden desarrollarse y fomentarse en la asignatura de historia y cómo los alumnos de primaria y secundaria pueden utilizar diversos ejemplos del pasado para desarrollar una actitud positiva hacia la identidad eslovena y la protección del patrimonio cultural esloveno; una actitud respetuosa hacia los derechos humanos y la ciudadanía democrática; hacia las diferentes culturas, religiones y naciones; y finalmente una actividad sociopolítica responsable. Se observó que los profesores de historia tienen muchas oportunidades de enseñar a los alumnos los valores relevantes de la ciudadanía democrática y de permitirles conocerse y comprenderse a sí mismos como individuos y como miembros de la comunidad local y global. Sin embargo, debería prestarse más atención a la historia eslovena contemporánea y a la ciudadanía activa.

Palabras clave: historia; educación cívica; plan de estudios; escuela primaria; escuela secundaria; Eslovenia.

CONTENTS: 1. Introduction. 2. Civic education in Slovenia. 3. The role of history in elementary schools. 4. The role of history in secondary schools. 5. Citizenship and civic competences in history curricula. 6. Teaching social and civic competences in the history classroom. 7. Conclusions. 8. Acknowledgements. 9. References. 10. Analysed history curricula. 11. Analysed history textbooks.

\section{INTRODUCTION}

The specific society in which we live and the specific nation to which we belong are, from the perspective of our collective national experience, a unique, vital and exceptional form of the human community, but they are simultaneously and undeniably an integral part of broader European and human history, which is by no means simply a continuous growth 'from the worst to the best', from the less human to the more human, and 'from the less developed to the more developed'; in reality, it is a highly contradictory process characterised by fluctuations and falls, duration and regressions. (Vodopivec, 2006, pp. 41-42).

The above quotation introduces the article which will attempt to examine civic education, in the broadest sense of the term, together with patriotic education. Above all, it will highlight the intertwining of patriotic and civic education, which is typical of Slovenian elementary and secondary education. 
Over the past ten years, several research studies have been conducted on civic and patriotic education and active citizenship in Slovenia. Their authors (Šimenc, 2012; Kukovič \& Haček, 2014; Radović \& Pušnik, 2011; Mandelc \& Banjac, 2016; Taštanoska, 2013) aimed to determine whether patriotic and civic education content is suitably integrated into elementary and secondary schools, and how this area could be improved further. They explored to what extent the elements of citizenship (i. e. the knowledge and understanding of the organisation of the state, active citizenship, respect for human rights, the protection of cultural heritage and the shaping of national identity) are included in the Slovenian school system. The studies paid special attention to patriotic education in relation to civic education.

For instance, Meglič (2006) believes that the elements of civic and patriotic education overlap in many aspects and are not mutually exclusive. However, the author ranks the homeland (the nation and national awareness) first, while ranking the state, i. e. civic education, second. He also believes that the love of one's homeland leads to a sense of belonging to the state (Meglič, 2006, pp. 68-69).

On the other hand, Vodopivec $(2006$, p. 38) states that the content of patriotic education is a specific area, dealing with society and the nation with its good and bad characteristics, while the goal of civic education is to shape a responsible, tolerant and active citizen who will strive for the pursuit of the principles of democracy and social solidarity in public life. Moreover, he proposes that patriotic education "should not instil in young people an uncritical and unconditional love of their homeland; rather, it should primarily encourage and co-shape a sense of responsibility for its democratic, culturally and pluralistically open and ecologically balanced development» (Vodopivec, 2006, p. 40).

Several other Slovenian historians and history teachers have joined in the discussions on the role of civic and patriotic education (Granda, 2006; Prunk, 2006; Valič Zupan, 2006), which has led to the renaming of the only subject that covers this topic in elementary school in its entirety. Originally, the subject was called ethics and society; it was renamed civic education and ethics, and later civic and patriotic education and ethics. The title currently in use is patriotic and civic culture and ethics, which indicates the increased importance of patriotic education in elementary schools in Slovenia.

Slovenian authors view civic education in the narrow and broad senses of the word, for example, Štrajn $(2006$, p. 85) views civic education in the narrow sense of the word as educating citizens, also for active citizenship, and as learning about the institutions of the state (e. g. Slovenia). Vodopivec (2006, p. 40), on the other hand, views civic education more broadly, proposing that it inform young people through debates, wherever possible, on their civil rights, on the principles and institutions of a democratic society, on the basic concepts of the constitutional order, on parliamentary and political life, on the operation of authorities, and on the situation in Europe and the world. 
Justin $(2006$, p. 91) similarly views civic education at two levels; the first, narrower level should entail the passing on of basic information about the constitution, laws, the political system, and education for basic civic virtues (respect for the law, a sense of belonging to the nation and state, solidarity in the immediate environment, participation in elections, etc.); at the second, broader level, civic education should develop critical and independent thinking in students, and make them think about the common foundation for society's values, about a just society and optimal democracy and enable them to develop public virtues, such as commitment to solving the problems of their own society and of the world.

According to Sardoč (2014, p. 11), there is no unambiguous answer to the question of what citizenship is, as it can be either a common status in a political community, a political identity or a normative ideal of a fully engaged member of a political community. Citizenship can refer to a single nation, a single country, to a region or to the world.

What should global citizenship education look like? Keaton (2010, pp. 245-246) lists the following characteristics of global citizenship education: a member of a nation is a citizen of the world; in addition to national organisations, international organisations are also important; human rights are based not only on nationality, but also on the global definitions of affiliation; besides national values, universal civic values are also taken into account (e. g. respect for diversity, cultural heritage and the environment; promoting solidarity and equality; assuming personal responsibility and acknowledging the importance of civic engagement, etc.).

Modern society is to shape different types of identities. To quote a former Slovenian minister of education:

All group identities of various levels and types - be it family, peer, local, regional, national, global, etc. - are reflected in a person's own identity. The more group identities a person adopts, the more he/she is 'equipped' for life in terms of socialisation, the more prepared he/she is to cope autonomously with the uncertainties that the 'risk society' brings with it on a daily basis. /.../ School, in the broadest sense of the word, has played and will surely continue to play a vital role in shaping civic and patriotic identity and culture. (Zver, 2006, p. 4).

How important is the subject of history in the civic education of young people in elementary and secondary schools? History can make a significant contribution to proper civic education, as it includes political history and demonstrates and explains the formation and fall of many countries and political entities; on the other hand, it can contribute to patriotic education through the knowledge and understanding of the historical events connected with the Slovenian nation.

Many European authors engaged in the study of history education have noted the great importance of civic education in the subject of history. They claim that 
it contributes to responsible citizenship and civic activity (Phillips, 2008), enables the social and moral development of young people through different approaches (projects, hometown activities, team research work, etc.) (Cooper, 2000) or contributes to the understanding of and participation in society. History is an activity and mode of engaging with the world (Chapman, 2021). For this reason, local, national and world histories are equally important (Phillips, 2002). A number of Slovenian authors emphasise that history is the one school subject without which there can be no citizenship (Granda, 2006; Prunk, 2006; Vodopivec, 2006; Justin \& Sardoč, 2003). Vodopivec $(2006$, p. 38) claims that the institutions, values and traditions of modern democracy are the product of longer historical developments, which can be adequately explained only in light of their formation and assertion in the past. Valič Zupan (2006, p. 114) states that history educates students to become active and responsible citizens who are aware of diversity; who are critical thinkers, tolerant, capable of independent thinking and co-operating with others; who are curious and interested in the past, present and future of their nation, and of broader European and global areas.

The purpose of this article is to explain the importance of patriotic and civic education in the subject of history in elementary and secondary schools in Slovenia. The article begins with a description of civic education in Slovenian elementary and secondary schools; it continues by explaining the role of history in the civic education of young people in elementary and secondary schools; it presents the findings of the analysis of current history curricula, which determine the ways in which civic education is integrated into history curricula in elementary and secondary schools, as well as the importance of Slovenian history. Finally, examples are given of how elementary and secondary school students can acquire active citizenship skills in history lessons.

\section{CIVIC EDUCATION IN SLOVENIA}

In Slovenian elementary and secondary schools, civic and patriotic education appears at three levels, just like in other European countries (Taštanoska \& Kresal Sterniša, 2013; European Commission, 2017). Firstly, as a cross-curricular theme; secondly, as a topic integrated into other subjects; and thirdly, as a separate subject (SVIZ, 2017; Barle Lakota \& Rustja, 2006, p. 7).

As a cross-curricular school theme, it is integrated into the general objectives of elementary and secondary education. The content and objectives of civic education are integrated into all subjects according to the principle of cross-curricular integration (Radović \& Pušnik, 2011, p. 138). Thus, the general curriculum for elementary and secondary schools envisages the integration of civic education into different subjects but it does not specify how it should be done. It leaves that up to the 
curricula of individual subjects. Students are to become qualified for active citizenship through various activities at the schools, e. g. during cultural, science, sports or technical activities, on field trips and while doing project and research assignments (Radović \& Pušnik, 2011, p. 145).

As a topic that has been integrated into individual subjects, civic education is mostly included in compulsory subjects in nine-year elementary schools (students aged from 6 to 15), e. g. in Slovenian language (grades 1 to 9), social studies (grades 4 and 5), history and geography (grades 6 to 9); it is also included in certain elective subjects in the field of social or natural sciences (grades 7 to 9), especially in the elective subject of civic culture (SVIZ, 2017). Likewise, in general secondary schools (students aged from 15 to 19), the topic of civic education has been integrated into compulsory subjects, especially into Slovenian language, history, geography and sociology. In secondary technical schools, it has been integrated into the subject of social sciences (this subject includes historical, geographical and sociological content).

The compulsory subject of patriotic and civic culture and ethics is taught as an independent subject in elementary schools (grades 7 and 8). Civic education is of special importance in the elementary school system, as is evident from the Elementary School Act (1996), where the main educational objectives include several objectives related to patriotic and civic education, namely:

educating for sustainable development and for active involvement in a democratic society /.../; developing an awareness of nationality and national identity, the knowledge of the history of Slovenians, their cultural and natural heritage, and promoting civic responsibility; educating for general cultural and civilisational values stemming from the European tradition; educating for respect and co-operation, for accepting diversity and for mutual tolerance, for respecting human rights and fundamental freedoms. (Elementary School Act, 1996, Article 2).

According to Kukovič and Haček (2014, p. 19), the subject of patriotic and civic culture and ethics in elementary schools is mostly about passing on the knowledge of society that enables young people to find answers to social and ethical questions on their own; to acquire ethical skills which are a prerequisite for independent and responsible social engagement; moreover, it enables the development of social and communication skills, and a democratic culture of communication; it enables the development of a sense of responsibility for one's own conduct and for the conduct of the community, of a considered and active attitude towards the principles of justice, equality, freedom and solidarity.

Interestingly, this subject includes a lot of topics relating to history. In a short research study, Radović and Pušnik (2011) found the inclusion of different historical content in the subject of patriotic and civic culture and ethics. For example, the topic of individuals and society relates to life in ethnically mixed communities, families in 
the past and present, the role of women in the past and present; the topic of human rights and responsibilities relates to the following content in history: formation of the USA, male and female fighters for human dignity and freedom throughout history, social engagement of famous Slovenian men and women, the United Nations, examples of social conflicts in the past and present, respect for rights throughout history; the topic of human diversity (from multiculturalism to interculturalism) relates to the richness of different cultures; the topic of values, beliefs and ethics relates to the following historical content: altered political and religious image of Europe, Protestantism, expansion of the Ottoman Empire, differentiation between morally excusable and inexcusable opposition to authorities and rules in the case of worldfamous persons, changes in values through time and place; the topic of democracy relates to Greek democracy, modern nations, the expansion of democratic rights in the second half of the 19th century, the democracy crisis and the rise of dictatorships and totalitarianisms, the integration of Europe and the European Community; the topic of patriotic and civic culture relates to independent Slovenia and its international integration; lastly, the topic of humanity and the future relates to numerous historical topics (globalisation and economic integration at the turn of the 21st century, the consequences of the use of modern scientific achievements, migration and intercultural contacts and conflicts) (Radović \& Pušnik, 2011, pp. 138-144).

Even though in recent years there have been proposals and requests to introduce an independent subject into secondary schools called active citizenship, they never bore fruit (STA, 2019). Instead, secondary school students have to attend special compulsory elective subjects that relate to peace education, family, nonviolence and civic culture.

It can be concluded that civic education has an important role in Slovenia and that it involves three different dimensions. The first dimension is the development of civic literacy which includes the knowledge of social and political institutions, the constitution, national identity, etc. The second dimension is the development of critical thinking and reasoning skills, of conflict resolution skills, of social and moral responsibility towards oneself and others, etc. The third dimension is participation in the activities relating to the life and work of the school (Barle Lakota \& Rustja, 2006, p. 7). All three dimensions are included in the subject of history in elementary and secondary schools.

\section{THE ROLE OF HISTORY IN ELEMENTARY SCHOOLS}

The fundamental values of education in the Republic of Slovenia come from the common European heritage of political, cultural and moral values, which are all based on human rights and the corresponding duties and the principles of plural democracy, tolerance, solidarity and the rule of law (Krek \& Metljak, 2011, p. 13). 
Slovenian elementary schools are compulsory for nine years. Children enter school at the age of six years and finish it at the age of fifteen.

Compulsory school subjects are: the mother tongue (Slovenian, Hungarian or Italian in the areas with these nationalities), mathematics, visual arts, music, environmental education, sports education, foreign language, social sciences, geography, history, natural sciences, techniques and technologies, home economics, patriotic and civic culture and ethics, natural sciences and techniques, physics, chemistry and biology. The compulsory part of the programme also includes extra-curricular activities (culture, science, technical and sports days).

Table 1. Total number of lessons per subject in the 9-year elementary schools (Eurydice, 2008/09, p. 69)

Subjects

\begin{tabular}{|c|c|}
\hline Subjects & Total number of lessons per subject \\
\hline Slovenian language & 1631.5 \\
\hline Mathematics & 1318 \\
\hline Sports education & 834 \\
\hline Foreign language & 656 \\
\hline Visual arts & 487 \\
\hline Music & 452 \\
\hline Environmental education & 315 \\
\hline History & 239 \\
\hline Geography & 221.5 \\
\hline Natural sciences and techniques & 210 \\
\hline Social sciences & 175 \\
\hline Natural sciences & 175 \\
\hline Techniques and technologies & 140 \\
\hline Physics & 134 \\
\hline Chemistry & 134 \\
\hline Biology & 116.5 \\
\hline Home economics & 87.5 \\
\hline Patriotic and civic culture and ethics & 70 \\
\hline
\end{tabular}

Total number of lessons per subject 
The subject of history is an independent and compulsory subject in elementary schools in the final four years. Table 1 shows that the total number of lessons (one lesson equals 45 minutes) for the subject of history in elementary school is 239 . The subject of patriotic and civic culture and ethics is another independent and compulsory subject and it has 70 lessons in two years. Elementary school students come across history as early as the 4th and 5th grades (ages 9 to 11 ) as part of the subject of social sciences. Within the historical content, students are able to describe local and Slovenian history, particularly the life of people in the past, which they compare to the life of today. Their spatial perception begins in their hometown and is then transferred to Slovenia and Europe (Social Sciences Curriculum, 2011, pp. 4-6).

Prior to 1991, the elementary school curriculum for history contained many objectives and a great deal of content relating to the history of Yugoslav nations and ethnicities, the Kingdom of Yugoslavia, the self-managing socialist Yugoslavia, Yugoslav nations during World War II (Trškan, 2013, p. 189). Students in elementary schools were educated for democratic relations in a socialist society, particularly in the spirit of Slovenian awareness and the brotherhood and unity of Yugoslav peoples and ethnicities (Trškan, 2012, p. 169). After 1991, there was much less content on the history of Yugoslav nations and more on Slovenian history. The curriculum of 1991 already included the disintegration of Yugoslavia and Slovenia's attainment of independence (Trškan, 2013, p. 189).

The first role of teaching and learning history at elementary school today is the informative role. History informs the learners about the most important events from local, regional, Slovenian, national, European and world history (History Curriculum, 2011, p. 4). Accordingly, by the end of elementary school, students are able to "acquire, expand and deepen their knowledge of the most important events, phenomena and processes from world, European, regional and national history» (History Curriculum, 2011, pp. 5-6).

Regarding patriotic education, Kukovič and Haček (2014) believe that history in elementary school should mainly focus on teaching the most important events in European, world and national history; on teaching Slovenian history and simultaneously developing an awareness of national identity and nationality; on imparting knowledge of cultural heritage in the general and national contexts, a sensitivity to European cultural and civilisational values and the importance of preserving Slovenian cultural heritage (History Curriculum, 2011, pp. 5-6, cited in Kukovič \& Haček, 2014, pp. 24-25).

The second role of teaching and learning history at elementary school is to train young people for historical thinking, reasoning, evaluation and historical research. For example, students learn how to form independent conclusions, views and opinions, empathise with different perspectives and find original answers and solutions. They also learn to present their knowledge orally, in writing, graphically or illustratively by using information technology (History Curriculum, 2011, p. 5). 
The third role of teaching and learning history at elementary school is to influence students' attitudes towards the world and their values, and to develop their social and civic competences. The most important general objective related to civic education is to deepen students' knowledge of Slovenian history and to develop an awareness of national identity and nationality, as well as to develop an awareness of the importance of their cultural heritage and environment through examples from local history (History Curriculum, 2011, pp. 5-6).

The history curriculum for elementary schools includes patriotic and civic elements, as students are required, during history lessons, to enumerate and explain the characteristics of Slovenian national symbols and of the symbols of the European Union; to assess the importance of preserving and protecting Slovenian, European and world cultural heritage and the environment; to enumerate and explain the political systems which committed crimes against humanity, genocides, the Holocaust and other forms of mass atrocities; to explain, using concrete examples, the importance of European institutions in the protection of human rights; to write an action plan in the context of European institutions in the case of a human rights violation (History Curriculum, 2011, p. 39).

According to the History Curriculum (2011), the content is divided into general (world history - approx. $30 \%$ of topics - and European history - approx. $55 \%$ of topics) and Slovenian history from prehistory to the 20th century (approx. $15 \%$ of topics). There are 39 different topics, which are arranged chronologically and thematically, approx. $25 \%$ are political and approx. $20 \%$ are social. Many topics involve everyday life in different historical periods. According to Kunaver (2008), the history curriculum for elementary schools has several advantages. Teachers can select elective topics and better plan and schedule the teaching of obligatory topics.

Sixth-grade students (aged from 11 to 12) learn about history, historical time, the first records, the construction of human dwellings through historical periods, inventions through the periods, the family through the centuries, the life and diet of people in the countryside and in towns, cultural heritage, customs and people's habits. The topics are: The Remnants of the Past - Getting to Know History; People Create, Reflect - Civil Engineering and Architecture; The Beginnings of Science; The Way of Life; Cultural Heritage, Manners and Customs.

Seventh-grade students (aged from 12 to 13) learn about the way of life and beliefs in prehistory and about archaeological sites in Slovenia, the characteristics of the ancient civilisations of the Americas, India and China, the development of ancient Greece and the Roman state, the characteristics of ancient culture and economy. When discussing the Middle Ages, they learn about the migration of peoples and the creation of European states and about mediaeval life, Slovenians in the Middle Ages, Southern Slavs and the Turkish Invasion of the Balkans. Outside of Europe, they become acquainted with India, China and the Mongol Empire in the Middle Ages. 
Eighth-grade students (aged from 13 to 14 ) learn about geographical discoveries, about Humanism and the Renaissance, about the Reformation and Protestantism in Europe and in Slovenia, about the exploration of Africa, the expansion of the Ottoman Empire, peasant revolts in Europe and in Slovenia, the Enlightenment and the political development of France and England, about the Hapsburg Monarchy during the reigns of Maria Theresa and Joseph II, about the formation of the USA, the revolution in France, the Napoleonic Wars, the characteristics of the Baroque, about industrialisation, about Europe and the Slovenians in the 19th century, about Japan and the USA in the 19th century, about the arts, the labour movement, the status of children and women in the 19th century, etc.

Ninth-grade students (aged from 14 to 15) become acquainted with World Wars I and II, the inter-war period, the Cold War, the decolonisation, industrialisation and economic development in the 20th century and with the globalisation in the 21st century, the development of science, with everyday life and with Slovenians in the 20th and 21st centuries.

In the last-mentioned topic, students learn to explain the reasons for the decision of Slovenians for their own independent state, to explain Slovenia's international integration, to describe the constitutional order and life and to explain the impact of the democratic political order of the Republic of Slovenia on people's lives (History Curriculum, 2011, p. 24).

According to Kukovič and Haček (2014), the elements of patriotic education appear proportionally to the advancement to a higher grade of elementary school. The most important content units for identifying the elements of patriotic and civic education are those relating to the history of Slovenian territory in the past, especially under the topic Slovenians in the 20th and 21st centuries, which also covers independent Slovenia and Slovenia's international integration (History Curriculum, 2011, p. 24, cited in Kukovič \& Haček, 2014, pp. 25-26).

Šepec (2018) demonstrates that the history of the independent Republic of Slovenia is discussed in the last grade of elementary school at the end of the school year; therefore, teachers devote a small number of lessons to it. Through empirical research, she found that history teachers devote between 1 and 4 lessons to discussing Slovenia's contemporary history from 1991 onwards (Šepec, 2018, pp. 8698 ), which is not nearly enough to teach elementary school students much about the 30 years of Slovenia's independent existence.

\section{THE ROLE OF HISTORY IN SECONDARY SCHOOLS}

Secondary education is free of charge and not compulsory. There are four main types of secondary education in Slovenia, where students can learn history: general 
secondary education (4 years), secondary technical education (4 years) and secondary vocational education ( 3 years).

General secondary education is carried out by general secondary schools, which are of three types: general, classical (with Latin and Greek) and professional. Professional schools have three specialisations: technical, artistic and economic. Compulsory four-year subjects are Slovenian language, mathematics, first and second foreign languages, history and physical education. Compulsory subjects are also geography, biology, chemistry, physics, music, art, psychology, sociology, philosophy and information science.

Table 2. Total number of lessons per subject in the 4-year general secondary schools (Eurydice, 2009/10, p. 25)

Subjects

Slovenian language

Mathematics

First foreign language

Second foreign language

Physical education

History

Geography

Biology

Chemistry

Physics

Music

Art

Psychology

Sociology

Philosophy

Information science
Total number of lessons per subject

560

560

420

420

420

280

210

210

210

210

70

70

70

70

70

70 
The subject of history is an independent and compulsory subject in all four years of general secondary schools (Table 2). Secondary vocational and technical education schools offer different programmes. Compulsory subjects in secondary technical schools are Slovenian language, mathematics, foreign language, physical education, geography, history, art, chemistry, biology, physics, information science and psychology. History is a compulsory subject only in secondary technical schools, where students have 103 history lessons in the first or second years (History Knowledge Catalogue, 2007). Short-term vocational schools offer the subject of social and natural sciences, comprising 248 lessons, of which social science and humanistic content is allocated 155 lessons and natural science content 93 lessons (Social and Natural Sciences Knowledge Catalogue, 2007). Secondary vocational schools offer the subject of social sciences, comprising 132 lessons, with one-third of the lessons intended for the historical content connected with Slovenian and world history (Social Sciences Knowledge Catalogue, 2007).

In history curricula for secondary schools published before 1991, numerous educational objectives were related to the brotherhood and unity of nations. Teachers had to develop a patriotic awareness in the students and deepen their love of the homeland of Yugoslavia (Trškan, 2012, p. 172). Because Slovenia was one of the six republics of the Socialistic Federal Republic of Yugoslavia, civic education sought to instil the young people with a positive attitude towards the state and solidarity and unity of the Yugoslav peoples. Prior to Slovenian independence, Slovenian curricula had to focus more on the Yugoslav identity rather than on the Slovenian one (Trškan, 2012, p. 169). After the independence and formation of Slovenia in 1991, Slovenian history was given greater importance in secondary school history curricula. Yugoslav identity and history were replaced by Slovenian identity and history. Slovenian identity was seen as linked more to Central and Western Europe than to the rest of the states of former Yugoslavia, especially after 2004 (Trškan, 2013, p. 190).

The history curriculum for general secondary schools today highlights history's important role in shaping Slovenian national awareness and national identity; it also emphasises European and individual identities. Seeing that Slovenian history is integrated into the broader Central European area, it enables secondary school students to better understand what events are influenced by and how they are interconnected (History Curriculum, 2008, p. 7).

Kukovič and Haček (2014) argue that it is important for the history curriculum to highlight that the purpose of history is to encourage curiosity for the past and present of the Slovenian nation and its achievements, thus creating a foundation for shaping the historical consciousness of Slovenian national identity and nationality (History Curriculum, 2008, p. 7, cited in Kukovič \& Haček, 2014, pp. 45-46).

The history curriculum for general secondary schools contains obligatory and elective topics, which are arranged or combined chronologically and thematically. 
Kukovič and Haček (2014, p. 45) estimate that the topics include the key historical events and processes which are important for understanding the cultural development of the human race and civilisation. Emphasis is also placed on the social and cultural topics and content relating to the history of everyday life in selected historical periods (History Curriculum, 2008, p. 10). The obligatory topics mainly include the political/military (approx. 35\% of the topics) and socioeconomic events (approx. $10 \%$ of the topics), while elective topics mainly include cultural history and everyday life. There are 28 different topics, approx. $25 \%$ of the topics include Slovenian history, approx. $45 \%$ of the topics include European history and approx. $35 \%$ world history. According to Brodnik (2008), the curriculum has many advantages, providing teachers with selectivity, openness and flexibility.

It should be added that history is also one of the elective subjects that students can choose for their Matura examination. The number of candidates who choose history as an elective subject in the Matura examination is roughly one-fifth of the generation taking the general Matura examination. Candidates fill out two written examination papers; one paper refers to national history and the other to European/world history. The data show that candidates achieve similar scores in both papers; in other words, there is no indication that they are more knowledgeable in Slovenian or world history (Šeruga, 2019, p. 93).

Repe (2005) writes that the Matura examination in history is a great achievement for Slovenia; it has conceptually changed history lessons in general secondary schools. He asserts that the Matura examination in history influences the overall education of general secondary school students, the shaping of historical awareness, the strengthening of national identity and the knowledge of secondary school students about other nations and civilisations. It also promotes the spirit of humanism, tolerance and multiculturalism (Repe, 2005, p. 388).

First-year students (aged from 15 to 16) learn about what history as a discipline studies, about the origin of the human race, the first civilisations, the Greeks and the Romans and about present-day Slovenia in prehistory and antiquity. The elective topics provide them with the knowledge about India, China and the Americas in the Middle Ages and about the everyday life of the first civilisations, the Greeks and the Romans. They are also taught the features of science, religion and art from prehistory to the Middle Ages (with emphases on Greek and Roman culture and Christianity).

Second-year students (aged from 16 to 17) learn about the formation of European countries after the fall of the Roman Empire (the Frankish monarchy, Italian city states, Papal States, the Netherlands and England), about the mediaeval colonisation and economic development in the Middle Ages and the modern period, about geographical discoveries, Humanism, the Renaissance, the Reformation, the Enlightenment, the period of absolutism, and the beginnings of industrialisation. The history of Slovenians is taught separately (the settlement of Slavs in the Eastern 
Alps, Slovenian territory in the Middle Ages, Turkish raids, peasant revolts and the Reformation in Slovenia).

Third-year students (aged from 17 to 18) learn about the following events: the equality ideas of the Enlightenment, the American Revolution, the French Revolution, Napoleon's dictatorship, the liberal movements and bourgeois revolutions of the 19th century, the national movements of the 19th century, the development of Slovenian national awareness from the end of the 18th century onwards, the economic development and formation of political parties in the 19th century, etc. It has three obligatory topics (The Ascent of the Bourgeoisie and the Introduction of Parliamentary Democracy; Troubled Waters: From National Movements to the First World War; The Slovenian National Movement) and four elective topics (The Splendour and Misery of Industrial Development; Everyday Life in the 19th Century; The Social Development in Slovenia in the 19th Century; Meeting Points of Cultures: The Far East, North and Latin Americas in the 19th Century). The elective content refers to the economic and social development of 19th century Slovenia and Europe; in the case of the non-European areas, it refers to the political and socioeconomic development of North and Latin Americas and of the Far East in the 19th century.

Fourth-year students (aged from 18 to 19) are thoroughly familiarised with the development of democracy in the 20th century, with Slovenian history in the 20th and 21st centuries, with World Wars I and II, with the Cold War and with the various economic and political integrations in Europe and the world in the 20th century. As part of the elective topics, students can learn about the migration of Asians, the political and economic migrations in the world in the 20th century, about multicultural societies, about science and technology in the 20th century and about global interdependence and human rights in the modern world. It has three obligatory topics (The Development of Democracy; Co-operation and Conflicts in the 20th Century; The Development of the Slovenian Nation in the 20th Century) and four elective topics (Civil Social Movements and Human Rights; The Migration of the Population; Science and Technology in the 20th Century; The Changing Ways of Life in Slovenia after the Second World War).

Three topics have to be underlined. In the first topic (The Development of the Slovenian Nation in the 20th Century), students learn about the factors leading to an independent state of Slovenia and its integration in European associations, and about the situation of Slovenians in the neighbouring countries, of migrant workers, emigrants and minorities. In the second topic (The Development of Democracy), students compare different forms of democratic orders in the past and present and the achievements in the development of democracy (The Enlightenment Idea of the Three Branches of Authority and the Development of Democracy until the 20th Century: Ancient Democracy, the Enlightenment, Development in the 19th Century; Democratic Systems between the Wars in the 20th Century; Totalitarian Systems: Fascism, National Socialism, Bolshevism; The Spread of Democracy after the Fall of 
the Berlin Wall in Europe and the World; Difficulties Faced by the Democratic Order in the Contemporary World). The third topic (Civil Society Movements and Human Rights) prepares the students for democratic citizenship (Movements for Freedom and Equality in the 19th Century; Women's Suffrage and the Inclusion of Women in Political Life; The Declaration on Human Rights; The Examples of Human Rights Violation in the 20th Century; Civil Rights Movements; Student Movements; Peace Movements; Global Interdependence and the Challenges of Human Rights in the Contemporary World) (History Curriculum, 2008, pp. 37-41).

The general objectives in the history curriculum for secondary technical schools envisage that students "acquire an appropriate attitude towards the most important events, phenomena and processes of Slovenian, European and world history» (History Knowledge Catalogue, 2007, p. 42).

The first part of the history curriculum for secondary technical schools includes obligatory content on the development of Slovenian national identity and the path to the Slovenian state in the 19th and 20th centuries, with the following topics: The Slovenian Lands and Slovenians in the Period up to the 18th Century (Introduction); Slovenians at the Time of the Enlightenment and National Awakening in the Hapsburg Monarchy from the Second Half of the 18th Century to 1848; Slovenians in 1848 and the National Programme "United Slovenia»; Slovenians in the Second Half of the 19th Century and at the Turn of the 20th Century; The First World War and Slovenians; Slovenians in the First Yugoslav State; The Second World War and Slovenians; Slovenians and Europe in the First Decade after the Second World War; Slovenia, the Most Developed Yugoslav Republic; The Yugoslav Crisis and the Slovenian Path to Independence; Europe and the Republic of Slovenia from the Attainment of Independence to the Present Day.

In the last-mentioned topic students become acquainted with the constitution of the Republic of Slovenia, elections, the electoral and party system, the efforts of the Republic of Slovenia for a faster economic and cultural development (denationalisation, privatisation, entrepreneurship, etc.), its membership of the European Union and NATO and the life of the people in the Republic of Slovenia from the achievement of independence to the present day (History Knowledge Catalogue, 2007, p. 13).

The compulsory elective part of the curriculum for secondary technical schools includes topics from European and world history, with the teacher selecting the topics that support students' missing knowledge and help give meaning to Slovenian history. These topics are The Early High Cultures and the Ancient World; Europe in the Middle Ages; Europe in Modern Times; The World and Europe in the 19th Century; Europe and the World in the 20th century (History Knowledge Catalogue, 2007, pp. 13-18).

Even though secondary vocational schools do not have the subject of history, historical content is included in the subject of social sciences, which contains the 
content of three subjects: history, geography and sociology. Topics with history content are: Domestic and Global Areas; The World at a Crossroads; Attitude towards the Environment and the Consequences of Human Intervention; The Dynamic Period of the Last Two Centuries; Life in the Community; Communication and Decisionmaking in a Community. In Domestic and Global Areas, students learn about the role of Slovenian state territory in European economic (mostly transport), political and cultural developments, the position of ethnic minorities along the Slovenian border and Slovenia's role in united Europe. In Communication and Decision-making in a Community, students learn about the government of the Republic of Slovenia, the definitions of human rights and fundamental freedoms, of economic and social relationships and the basic definitions in the Constitution of the Republic of Slovenia. In The Dynamic Period of the Last Two Centuries, students are taught the reasons behind the dissolution of the Socialist Federal Republic of Yugoslavia and Slovenia's attainment of independence; furthermore, they learn about Slovenia's efforts to join European organisations (Social Sciences Knowledge Catalogue, 2007, pp. $4,7 \& 9)$.

The topic Life in the Community contains objectives that also relate to world history or the world community, teaching students to:

understand the cultural plurality of contemporary societies (especially youth subcultures and countercultures) and relations between cultures; understand the processes of the creation and changing of peoples and nations and the problems of relations between nations (prejudice, xenophobia, genocide, coexistence, etc.); get to know the social and cultural functions of religion, the processes of the changing of religions and the social conditions of religious pluralism and (in)tolerance. (Social Sciences Knowledge Catalogue, 2007, p. 7).

When it comes to history in all secondary schools, Kukovič and Haček (2014, p. 46) likewise state that all the content relating to the history of Slovenian territory from prehistory to the present day contains patriotic elements, broadly speaking, and is important for civic education. They believe that the most important topic relating to civic education is the topic of Slovenia's attainment of independence in the late 20th century, allowing students to form their opinion about resolving border issues, recognise the factors leading to the birth of Slovenia, draw conclusions regarding Slovenia's involvement in European organisations and determine the position and problems of Slovenians living in neighbouring countries (History Curriculum, 2008, p. 40, cited in Kukovič \& Haček, 2014, p. 46). They also point out that teaching the topic of Slovenia's attainment of independence and of Slovenia after 1991 just before finishing elementary and secondary school education is a disadvantage. They claim that the "period of the attainment of independence and of forming the independent Republic of Slovenia is key to developing national 
awareness and nationality, to developing a sense of patriotic and civic duty and, last but not least, to strengthening active citizenship among secondary school students» (Kukovič \& Haček, 2014, p. 47).

\section{CITIZENSHIP AND CIVIC COMPETENCES IN HISTORY CURRICULA}

In this part of the article, a brief theoretical research study is presented which aimed to determine what civic competences are included in contemporary elementary and secondary school history curricula. It was assumed that civic competences were mainly related to Slovenian and European identity and cultural heritage.

The study encompassed four history curricula: the curriculum for elementary schools, the curriculum for general secondary schools, the curriculum for secondary technical schools, the curriculum for secondary vocational schools and the curriculum for social sciences (only its historical content). The findings are also based on two previously published research studies (Trškan, 2012; Trškan, 2014).

The history curriculum for elementary schools affirms that history (in addition to patriotic and civic culture and ethics) should communicate to students the values important from the point of view of education for democratic citizenship. History is the subject that enables learning about and understanding oneself as an individual and as a member of the local community and society (History Curriculum, 2011, p. 4).

The main objectives envisage students acquiring the following skills in relation to civic education. By the end of elementary school, students are able to:

- develop the ability to understand and respect different cultures, religions, races and communities;

- condemn crimes against humanity, genocides, the Holocaust and other forms of mass atrocities;

- condemn political systems that do not respect human rights;

- develop susceptibility to the values that are important for living in today's democratic society, e. g. tolerance in dealing with and relating to each other;

- respect for differentness and diversity, mutual co-operation, respect for human rights and democratic citizenship. (History Curriculum, 2011, p. 6).

The history curriculum encourages teachers to actualise historical findings and co-operate with other institutions (e. g. museums, archives, libraries) so that students can actively comprehend the contemporary world and develop a positive attitude towards preserving and protecting cultural heritage (History Curriculum, 2011, p. 41).

According to the history curriculum for general secondary schools, history holds an important role in the formation of Slovenian national awareness and 
national identity, while European and individual identities are also emphasised (History Curriculum, 2008, p. 7). The history curriculum includes the following objectives among the general objectives regarding the knowledge and understanding of historical events, of the phenomena and processes of the past and present either at home or abroad: students become aware of the importance of Slovenian, European and global cultural heritage, they learn to value democratic and responsible citizenship, they learn to respect human rights, equality and democracy and to condemn all crimes against humanity, they develop views on the world that respect human rights, equality and democracy, as well as democratic and responsible citizenship through chosen examples from history; they learn to respect differences between beliefs, cultures and communities and they develop a positive attitude towards diversity, multiculturalism and different social models (History Curriculum, 2008, pp. 8-9).

According to the history curriculum, civic and citizenship skills can be developed and promoted in history classes by:

- generating knowledge about a multicultural European society and teaching about its main social, economic and political milestones;

- $\quad$ positioning the national identity within the common European identity;

- encouraging intercultural dialogue and tolerance;

- developing cultural dialogue and taking into account and respecting different views and by defending one's own views and arguments that support them;

- developing an environment for overcoming prejudices and stereotypes;

- developing and encouraging positive attitudes towards democracy, respect for human rights, equality and responsible and critical citizenship;

- understanding the basic international documents that define and describe human and civil rights;

- learning about past and present events and trends in Slovenian, European and world history;

- understanding the goals of various social and political movements;

- understanding European organisations and the structures of the European Union;

- understanding and respecting various faiths and ethnic groups;

- $\quad$ respecting democratic principles and being willing to participate in the democratic parliamentary system. (History Curriculum, 2008, p. 11).

According to the curriculum, history teaching can promote cultural awareness and expression by helping students to develop an appreciation of local, national and European cultural heritage, by fostering positive attitudes towards local, national and European cultural heritage, positive attitudes towards the importance of preserving and protecting cultural heritage, and by promoting respect for cultural diversity and intercultural dialogue (History Curriculum, 2008, p. 12). It advises teachers to include the activities that develop values characteristic of a plural and 
tolerant society and to discuss different historical topics from a local, regional, national or European point of view (History Curriculum, 2008, p. 58).

In the history curriculum for secondary technical schools, the general objectives state that students will develop a tolerant attitude towards different nations, races, religions, religious movements and people who think differently in various historical periods. They become aware of the reasons for the differentness and diversity of the world (multiperspectivity, tolerance) (History Knowledge Catalogue, 2007, pp. 42-43).

The subject of social sciences in secondary vocational schools encompasses the cultural and social dimension of citizenship in its very name. Therefore, this subject primarily helps secondary school students to develop skills in non-violent conflict resolution; to recognise and accept differences; to take responsibility for improving life at the local level or even for jointly creating European and global citizenship; to become qualified for active citizenship and for building a more equal society. It helps students gain the knowledge, abilities and skills that will help them enter "working life and society as fully fledged citizens able to assert their civil rights and duties in a responsible and critical way, while ensuring their own healthy physical and mental development» (Social Sciences Knowledge Catalogue, 2007, p. 2).

If we sum up all the history curricula in elementary and secondary schools, we can see that historical content enables young people to gain the knowledge they require to understand the importance of Slovenian tradition and of preserving national identity, to gain the civic competences that are important for independent and critical thinking and for making decisions on the fundamental issues in society and the state, for participation in political life, institutions and other social organisations, first in the local community and then, more broadly, at the national level.

\section{TEACHING SOCIALAND CIVIC COMPETENCES INTHE HISTORY CLASSROOM}

In order to teach in elementary and secondary schools, Slovenian teachers must complete the second cycle of the Bologna system university studies with the pedagogical orientation (a total of 300 ECTS of the first and second cycles together). In Slovenia, the programmes are offered by the Universities of Ljubljana, Maribor and Primorska.

The second cycle study programmes of History contain fewer lectures and more independent work and practical training. They prepare students quite well for teaching history at elementary and secondary schools in Slovenia. Students - future teachers can choose a single-discipline study programme of history or a double-discipline study programme of history in combination with another study programme. All study programmes are evaluated regularly, which means that the 
teaching content, learning and teaching methods and learning outcomes can be updated continuously (Trškan, 2015, p. 106).

If students have completed a non-pedagogical study programme of History, they must take an additional post-graduate pedagogical course leading to the teaching qualification. Before applying for a job at a school, they have to acquire practical skills during traineeship (which lasts for ten moths in an elementary or secondary school) and pass the State Teacher Certification Examination.

The official teaching language in schools and other institutions in the Republic of Slovenia is Slovenian. In the Slovenian Istria, the members of the Italian ethnic community have lessons in Italian, with the obligatory subject of Slovenian. In other schools in the Slovenian Istria the subject of Italian is obligatory in elementary and secondary schools. In the area also inhabited by the members of the Hungarian ethnic community, lessons in elementary and secondary schools are carried out bilingually in the Slovenian and Hungarian languages (Šverc et al., 2007, p. 66).

History teachers can teach two subjects in elementary schools (history and patriotic and civic culture and ethics) and two subjects in secondary schools (history and social sciences: only its history content).

It should be pointed out again that students in elementary schools have the compulsory subject of patriotic and civic culture and ethics, where they learn about their homeland, the state, active democratic citizenship and current world problems. The empirical study conducted by Zupančič (2021) shows that both students and teachers find the knowledge of history and historical facts important for learning and understanding the learning content in this subject. In teachers' and students' opinion, the content units which relate to history the most are The Community of the Citizens of the Republic of Slovenia; Democracy Up Close; Belief, Religions, the State; Slovenia, the European Union, the World (Zupančič, 2021).

Karba (2011) claims that the difference in how content is discussed in the subjects of patriotic and civic culture and ethics and history lies in the temporal dimension.

History discusses content from the perspective of its development through time - the past is for the present and the future. It places great emphasis on temporal and causal dimensions. On the other hand, patriotic and civic culture and ethics usually focuses on the present with a strong emphasis on the future. However, to gain a deeper understanding of contemporary social phenomena, relationships, movements, the functioning of political systems and problems, we need a broader knowledge of history. Looking at the content from the perspective of interdependence between individual components (cause, reason, actors, sources, consequences, forms, methods of resolution, open issues, etc.) leads to a higher quality of young people's knowledge about the functioning of society and about the active/responsible role of individuals in this society. (Karba, 2011, p. 264). 
The main characteristics of the content of contemporary Slovenian history textbooks are visual materials, passages from written sources, concepts, timelines and various questions, in addition to the main text of the textbook. The textbooks include topics connected with Slovenian, European and world history.

The percentages of Slovenian, European and world history in textbooks can be determined by the number of pages or by the number of topics. Tables (3-5) show the number of the topics related to Slovenian, European and world history. Considering the fact that European history is embedded in world history, the number was defined on the basis of the predominant theme. In addition, the number of the topics in which either political or social history is predominant is also given.

Table 3. Number of topics in elementary school textbooks for history

\begin{tabular}{|c|c|c|c|c|c|}
\hline $\begin{array}{l}\text { Textbooks for } \\
\text { elementary } \\
\text { schools } \\
\text { (Rokus Klett) }\end{array}$ & $\begin{array}{l}\text { Number of } \\
\text { topics with } \\
\text { Slovenian } \\
\text { history }\end{array}$ & $\begin{array}{c}\text { Number of } \\
\text { topics with } \\
\text { European } \\
\text { history }\end{array}$ & $\begin{array}{l}\text { Number of } \\
\text { topics with } \\
\text { world history }\end{array}$ & $\begin{array}{l}\text { Number of } \\
\text { topics with } \\
\text { predominant } \\
\text { political } \\
\text { history }\end{array}$ & $\begin{array}{l}\text { Number of } \\
\text { topics with } \\
\text { predominant } \\
\text { social history }\end{array}$ \\
\hline
\end{tabular}

Textbook for the 6th grade (Verdev, 2016)

Textbook for the 7 th grade (Razpotnik \& Snoj, 2018)

Textbook for the 8th grade (Mirjanić et al., 2016)

Textbook for the 9 th grade (Razpotnik \& 24

Snoj, 2017)

Total number 42 86 65 66 28 193 topics /\%

$44.5 \%$

$33.5 \%$

$34 \%$

European

history)

0

4

9

8

10

19

6

15

38

10

$22 \%$ $14.5 \%$ 
Table 4. Number of topics in general secondary school textbooks for history

\begin{tabular}{|c|c|c|c|c|c|}
\hline $\begin{array}{l}\text { Textbooks } \\
\text { for general } \\
\text { secondary } \\
\text { schools (DZS) }\end{array}$ & $\begin{array}{c}\text { Number of } \\
\text { topics with } \\
\text { Slovenian } \\
\text { history }\end{array}$ & $\begin{array}{c}\text { Number of } \\
\text { topics with } \\
\text { European } \\
\text { history }\end{array}$ & $\begin{array}{l}\text { Number of } \\
\text { topics with } \\
\text { world history }\end{array}$ & $\begin{array}{c}\text { Number of } \\
\text { topics with } \\
\text { predominant } \\
\text { political } \\
\text { history }\end{array}$ & $\begin{array}{l}\text { Number of } \\
\text { topics with } \\
\text { predominant } \\
\text { social history }\end{array}$ \\
\hline
\end{tabular}

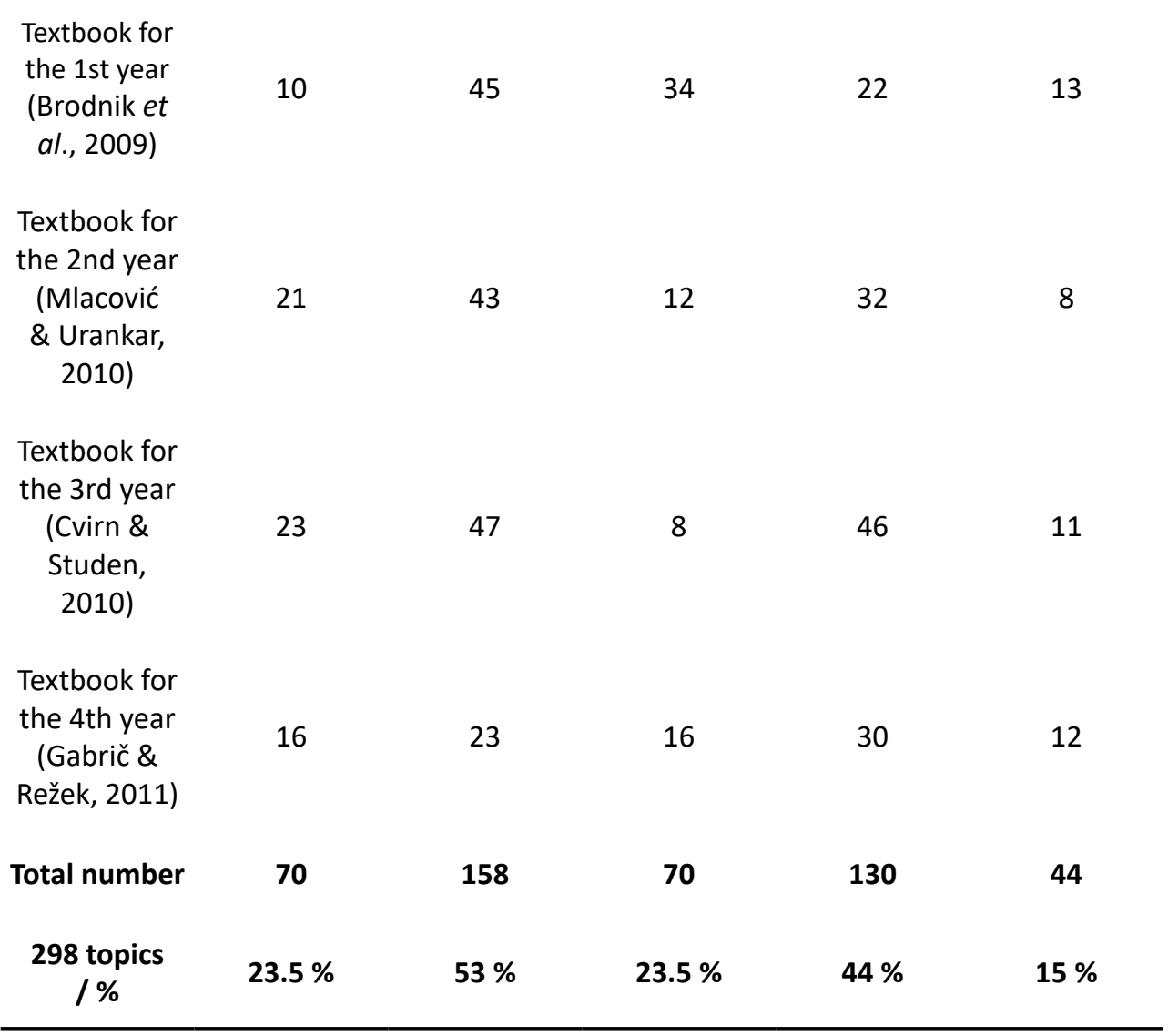


Table 5. Number of topics in secondary technical school textbook for history

\begin{tabular}{cccccc}
$\begin{array}{c}\text { Textbooks for } \\
\text { secondary } \\
\text { technical } \\
\text { schools (DZS) }\end{array}$ & $\begin{array}{c}\text { Number of } \\
\text { topics with } \\
\text { Slovenian } \\
\text { history }\end{array}$ & $\begin{array}{c}\text { Number of } \\
\text { topics with } \\
\text { European } \\
\text { history }\end{array}$ & $\begin{array}{c}\text { Number of } \\
\text { topics with } \\
\text { world history }\end{array}$ & $\begin{array}{c}\text { Number of } \\
\text { topics with } \\
\text { predominant } \\
\text { political his- } \\
\text { tory }\end{array}$ & $\begin{array}{c}\text { Number of } \\
\text { topics with } \\
\text { predominant } \\
\text { social history }\end{array}$ \\
\hline $\begin{array}{c}\text { Textbook for } \\
\text { the 1st or } \\
\text { 2nd year } \\
\text { (Karlovšek } \\
\text { \& Robnik, } \\
\text { 2014) }\end{array}$ & 51 & 41 & 7 & 53 & 4 \\
$\begin{array}{c}\text { Total num- } \\
\text { ber: }\end{array}$ & $51.5 \%$ & $41.5 \%$ & & & \\
$\begin{array}{c}99 \\
\text { topics / } \%\end{array}$ & & & & \\
\hline
\end{tabular}

As is evident from the tables (3-5), the majority of topics relate to European history and the fewest to world history. Quite a few topics also include political history, which means that teachers are able to apply the principles of historicalness and contemporaneity. These two principles can be realised through tasks and questions that ask students to recognise elements from the past and make them relevant.

The tables also show that Slovenian history is discussed much more in the history textbooks for secondary technical schools (approx. 50\%) and less in the history textbooks for elementary and general secondary schools (approx. 20\%). On the other hand, there is a much higher number of political topics in the textbooks for secondary technical and general secondary schools. Vodopivec (2006, p. 42) recommends that teachers should discuss topics that have been placed in a wider temporal and development context and make them relevant through contemporary comparisons and by drawings parallels with contemporary Slovenian history.

Teachers have various opportunities to incorporate local history into their discussion of Slovenian history (Trškan, 2008; Trškan, 2017). The history of students' hometown also plays an important role in their civic education, because they can come «to know the life stories of specific people and understand the interests of individuals and their motives for political, volunteer, cultural, humanitarian and environmental commitment» (Justin, 2006, p. 90).

Modern approaches to history lessons in Slovenia are founded on experiential learning, multisensory learning, interdisciplinary learning, learning through information and communications technology, learning through critical thinking, problem-based learning, learning through didactic games, learning through ob- 
servation, research-based and project-based learning and learning with emphasis on communication activities (Haydn, 2012; Cooper, 2013; Gershon, 2013; Brodnik et al., 2010; Razpotnik, 2011; Brodnik et al., 2013; Brodnik et al., 2018). Using different modern teaching approaches in history lessons enables an interactive imparting and understanding of learning content, which can be quite complex for students as it contains a great deal of factual data and information. In order to develop social and civic competences, history curricula recommend using debates, discussions, talks or role-playing about various contemporary political and social issues, thus developing a culture of dialogue. The subject of history teaches the basic terms and concepts which are also included in history curricula. A few examples for the history of the 20th and 21st centuries are democracy, the constitution, European integration, the national issue, democratisation, citizenship, gender equality, globalisation, civil society movements, intercultural dialogue, etc. Using communication methods, students can talk about the development and importance of human rights, the development of political parties, women's role in society, national symbols, etc.

Burbules (1993, pp. 112-130, cited in Marentič-Požarnik \& Plut-Pregelj, 2009, p. 74) defines four types of true, authentic dialogue during lessons: dialogue as teaching (critical attitude/convergent knowledge), dialogue as discussion (inclusive attitude/divergent knowledge), dialogue as debate (critical attitude/divergent knowledge) and dialogue as searching and researching (inclusive attitude/convergent knowledge).

During dialogue the teacher helps students achieve the expected outcome in the learning process. The dialogue can be steered towards searching, researching, problem solving, making moral judgements, etc., with students not only searching for and learning new information, opinions and views, but also arguing why one solution is more suitable than another (Marentič-Požarnik \& Plut-Pregelj, 2009, p. 76). A study (Radović \& Pušnik, 2011, pp. 90 \& 127) has also determined that we need to arouse students' interest in citizenship and active participation through activities such as dialogues, research, interviews, writing articles, preparing exhibitions, debates, etc. Turnšek Hančič (2010, pp. 246-247) maintains that in order to promote active citizenship teachers can introduce a critical discussion, listening to differentminded people, intercultural dialogue and methods of experiential learning, which would make this new experience more personal for the students.

The use of discussion allows students to form their own opinions about phenomena, increase their interest in different topics and develop their co-operative skills. They also become more confident, more sensitive to different views and ways of thinking, they begin to think critically and gain a sense of belonging to the group (Tomić, 2003, p. 137). During the discussions, they are able to solve problems that come from their home environment and later from their wider environment. Justin (2006, p. 98) asserts that the issue of social cohesion at the local level becomes a 
starting point for the issue of social cohesion at the national level. The latter can progress to the international community/level.

The history curriculum for elementary schools recommends project work, research work, field work, discovery learning, co-operative learning, role playing and simulations, independent work with different sources (written, pictorial, oral and information and communications technology) and visits to museums, archives and libraries. Also, history curricula for different secondary schools suggest various activities that develop awareness of the values that are characteristic of the plural and tolerant concepts of democratic societies. They recommend the use of historical sources and different forms of communication (oral or written, debate techniques), project work, role playing, co-operative work and visits to museums, local historical sites and historic centres (Trškan, 2012, pp. 181-182). Teachers need to include the forms of learning which are "relevant (designing learning activities around real situations in the life of the school or college, the community or the wider world); collaborative (employing group-work and co-operative learning); interactive (teaching through discussion and debate)» (Huddleston, 2007, pp. 28-29).

Of course, there are other ways to make young people in elementary and secondary schools interested in state-level political engagement and gain a more positive attitude towards active citizenship. Sardoč (2006, pp. 104-105) argues that actively involving students in the various activities implemented in the school setting can help develop the basic competences of education for democratic citizenship and future citizens.

\section{CONCLUSIONS}

The article has explained how civic and patriotic education is implemented in the subject of history in elementary and secondary schools in Slovenia. Slovenian schools as institutions and, through them, their teachers help to shape the ideas and values of young people.

The compulsory subject of patriotic and civic culture and ethics occupies an important place in elementary schools in Slovenia. However, history in elementary and secondary schools also contributes to civic education and emphasises the importance of understanding other people and cultures, promotes teamwork and co-operation between elementary and secondary school students and stresses the importance of active citizenship (participation in the hometown, elections, etc.), patriotism and respect for one's civil rights and civic duties, as well as the importance of cultivating a positive attitude towards the state and its institutions. It also contributes to respect for human and civil rights and the protection of natural and cultural heritage and national identity. 
The analysis of contemporary Slovenian history curricula for elementary and secondary schools has shown that they contain various elements of patriotic and civic education. The elementary school curriculum focuses on developing students' awareness of national identity and belonging on the one hand, and respect and tolerant attitudes towards other cultures, religions and races on the other. In secondary schools, the curricula emphasise the importance of history for the formation of Slovenian national awareness and identity, with European and individual identities also being important. History educates elementary and secondary school students to become democratic citizens, as it emphasises democratic values (respect for cultural heritage, human rights, equality, democracy, different religions, cultures and communities, different views and interpretations, opinions and points of view, etc.).

The analysis of the selected contemporary history textbooks has also shown that history plays an important role in the formation of the Slovenian, European and individual identities. Through various examples from the past, students can develop their own worldview that respects human rights, equality and democracy, as well as build their sense of democratic and responsible citizenship. Through various examples from the past, students can also condemn crimes against humanity, genocide, the Holocaust and other forms of the mass violation of human rights. In history classes, students can develop their social and civic competence, intercultural dialogue and tolerance.

According to the recommendations of all history curricula, teachers can, for example, include activities in their lessons that promote the development of the values typical of pluralistic and tolerant societies and teach different historical topics from a local, regional, national or European perspective (e. g. project work, research work, fieldwork, learning through discovering, co-operative learning, roleplays and simulations, independent work with different sources, visits to museums, archives and libraries). In addition, history teachers can use modern approaches to contribute to youth civic engagement (e. g. solving the problems of class, school or life, youth participation in various projects and organisations, media education, etc.). History lessons can include various elements through which students learn what rights and responsibilities people had in the past and how adults and young people participated in the work of the local community. In recent years, we have noted that, very appropriately, the Slovenian Ministry of Education supports the programmes for continuous teacher training in sustainable development with a focus on active citizenship and integration with global learning (Ministry of Education, Science and Sport, 2021).

Elementary and secondary school students learn about the formation of the independent state of Slovenia and the process of achieving independence (the content related to the Republic of Slovenia includes Slovenia's attainment of independence, international recognition and integration, as well as foreigners, emigrants, migrant workers and minorities in Slovenia). However, they learn about this only 
at the end of elementary or secondary school, which means that teachers cannot devote an adequate number of lessons to the contemporary history of Slovenians.

According to the results of some research studies (Radović \& Pušnik, 2011, Kukovič \& Haček, 2014; Šepec, 2018), the achievement of Slovenia's independence, its history in the last 30 years and the key elements for strengthening national awareness should be discussed more in history lessons (e. g. familiarity with the Slovenian flag, coat of arms, anthem, meritorious Slovenians, national holidays, etc.). They suggest that teachers should stimulate young people's interest in reading scholarly texts, watching TV programmes or looking up information about recent Slovenian history online.

Perhaps in the future, the content of history curricula will be changed, and it will be possible to devote more lessons to the Republic of Slovenia, which celebrates its 30th anniversary in 2021.

Research shows that the subject of history in Slovenian elementary and secondary schools has a great impact on the formation of young people's personality, as it contains countless examples that demonstrate the humanistic significance of history and moral-ethics, patriotic and civic education. On the one hand, history offers young people a number of opportunities to develop an awareness of nationality, cultural and linguistic heritage and diversity; on the other hand, it enables a more intensive, in-depth and active consideration of historical processes and phenomena on European and global scales. History lessons can be a real world for students, from which they can learn something for the present and about contemporary socio-political life.

Let us conclude with the words of the same Slovenian historian and professor we started with:

History in school (as well as history in general) should be designed as a subject that tries to broaden a (young) person's conceptions of time and space; on the one hand, to familiarise him/her with the 'path' that 'led us to where we are', and on the other hand, to qualify him/her for an independent and critical assessment of society and his/her environment. (Vodopivec, 2006, p. 41).

\section{ACKNOWLEDGEMENTS}

The authors acknowledge the project «Schools and Imperial, National, and Transnational Identifications: Habsburg Empire, Yugoslavia, and Slovenia» (J6-2573) was financially supported by the Slovenian Research Agency. 


\section{REFERENCES}

Barle Lakota, A. \& Rustja, E. (2006). Ugotovitve posveta državljanska in domovinska vzgoja in nastanek zbornika - Kako naprej? [Findings of the Meeting on Civic and Patriotic Education and the Creation of the Proceedings - How to Proceed?]. In A. Barle Lakota \& E. Rustja (eds.), Državljanska in domovinska vzgoja [Civic and Patriotic Education] (pp. 6-9). Slovenska Bistrica: Beja.

Brodnik, V. (2008). Posodabljanje učnih načrtov za zgodovino v gimnaziji. [Updating History Curricula in Secondary School]. Zgodovina v šoli, 17(1-2), pp. 24-36.

Brodnik, V., Bregar Mazzini, S., Ferjanc, S., Gaber, B., Gajski, P., Kristovič Sattler, S., Kunaver, V., Nemec, B., Pečoler, L., Praznik Lokar, B., Rode, M. \& Šifrer, M. (2013). Posodobitve pouka v osnovnošolski praksi, Zgodovina. [Modernisation of Lessons in Elementary Practice, History]. Ljubljana: Zavod Republike Slovenije za šolstvo.

Brodnik, V., Gaber, B., Holcar Brunauer, A., Bregar Mazzini, S., Štampfl, P., Čas, M., Kreč, T., Krivec, D. \& Babič, D. (2018). Formativno spremljanje pri zgodovini: priročnik za učitelje. [Formative Monitoring in History: A Handbook for Teachers]. Ljubljana: Zavod Republike Slovenije za šolstvo.

Brodnik, V., Popovič Lozar, G., Krivec Čarman, D., Stergar, T., Burjak, M., Bizjak, S., Globočnik, M., Gerden, V. \& Zgaga, S. (2010). Posodobitve pouka v gimnazijski praksi, Zgodovina. [Modernisation of Lessons in Secondary Practice, History]. Ljubljana: Zavod Republike Slovenije za šolstvo.

Chapman, A. (Ed.). (2021). Knowing History in Schools. Powerful Knowledge and the Powers of Knowledge. London: UCL Press. https://doi. org/10.14324/111.9781787357303

Cooper, H. (2000). The Teaching of History in Primary Schools. Implementing the Revised National Curriculum. London: David Fulton Publishers. https://doi. org/10.4324/9780203074817

Cooper, H. (Ed.). (2013). Teaching History Creatively. London, New York: Routledge. https://doi.org/10.4324/9780203074817

Elementary School Act. [Zakon o osnovni šoli]. (1996). http://pisrs.si/Pis.web/ pregledPredpisa?id=ZAKO448 
European Commission. (2017). Citizenship Education at School in Europe. Eurydice Report. Luxembourg: Publications Office of the European Union. https://doi. org/10.2797/449741

Eurydice. (2008/09). Organisation of the Education System in Slovenia, 2008/09. https://estudandoeducacao.files.wordpress.com/2011/05/eslovc3aania.pdf

Eurydice. (2009/10). Structures of Education and Training Systems. Slovenia, 2009/10 Edition. http://www.impletum.zavod-irc.si/docs/Skriti_dokumenti/Structures_ of_Education_and_Training_Systems_in_Europe_2009-10_edition_Slovenia. pdf

Gershon, M. (2013). Secondary Starters and Plenaries: History: Ready-to-Use Activities for Teaching History. London: Bloomsbury.

Granda, S. (2006). Državljanska ali domovinska vzgoja? [Civic or Patriotic Education?]. In A. Barle Lakota \& E. Rustja (eds.), Državljanska in domovinska vzgoja [Civic and Patriotic Education] (pp. 22-37). Slovenska Bistrica: Beja.

Haydn, T. (Ed.). (2012). Using New Technologies to Enhance Teaching and Learning in History. London, New York: Routledge. https://doi.org/10.4324/9780203075593

Huddleston, E. (Ed.). (2007). Tool on Teacher Training for Education for Democratic Citizenship and Human Rights Education. Council of Europe. https://rm.coe. int/16802f7279

Justin, J. \& Sardoč, M. (Eds.). (2003). Državljanska vzgoja pri pouku zgodovine, geografije in slovenščine. [Civic Education in History, Geography and Slovenian Lessons]. Ljubljana: i2.

Justin, J. (2006). Državljanska vzgoja: Slovenija in Evropa [Civic Education: Slovenia and Europe]. In A. Barle Lakota \& E. Rustja (eds.), Državljanska in domovinska vzgoja [Civic and Patriotic Education] (pp. 90-99). Slovenska Bistrica: Beja.

Karba, P. (2011). Prepletenost predmetov zgodovine in državljanske in domovinske vzgoje ter etike v programu osnovne šole. [The Intertwining of Subjects of History and Civic and Patriotic Education and Ethics in the Elementary School Programme]. In D. Trškan (ed.), Trojarjev zbornik [The Trojar's Proceeding] (pp. 261-266). Ljubljana: Znanstvena založba Filozofske fakultete. 
Keaton, A. (2010). Vzgoja državljanov Evrope. Od nacionalnega do postnacionalnega modela evropske državljanske vzgoje. [Educating Europe's Citizens. From National to Post-national Model of European Citizenship Education]. In J. Pikalo (ed.), Državljanstvo in globalizacija. K državljanski vzgoji za sodobni svet [Citizenship and Globalization. Towards Civic Education for the Modern World] (pp. 239-268). Ljubljana: Založba Sophia.

Krek, J. \& Metljak, M. (Eds.). (2011). Bela knjiga o vzgoji in izobraževanju v Republiki Sloveniji. [The White Book on Education in the Republic of Slovenia]. Ljubljana: Zavod Republike Slovenije za šolstvo. https://pismenost.acs.si/wp-content/ uploads/2017/09/Bela-knjiga-o-vzgoji-in-izobra\%C5\%BEevanju-v-RS-2011.pdf

Kukovič, S. \& Haček, M. (2014). Elementi domovinske in državljanske vzgoje ter aktivnega državljanstva v učnih načrtih slovenskih osnovnih in srednji šol. Analiza kurikulov. [Elements of Patriotic and Civic Education and Active Citizenship in the Curricula of Slovenian Elementary and Secondary Schools. Analysis of Curricula]. Ljubljana: Zavod Republike Slovenije za šolstvo, Ministrstvo za izobraževanje, znanost in šport. https://www.zrss.si/projektiess/gradiva/Projekt12_Analiza_ kurikulov_Elementi_DDV.pdf

Kunaver, V. (2008). Posodabljanje učnih načrtov za zgodovino $v$ osnovni šoli. [Updating History Curricula in Elementary School]. Zgodovina v šoli, 17(1-2), pp. 20-23.

Mandelc, D. \& Banjac, M. (Eds.). (2016). Prispevki in razprave $k$ domovinski in državljanski vzgoji in etiki: nacionalno preverjanje znanja 2014/15. [Contributions and Discussions to Patriotic and Civic Education and Ethics: National Evaluation of Knowledge 2014/2015]. Ljubljana: Državni izpitni center.

Marentič-Požarnik, B. \& Plut-Pregelj, L. (2009). Moč učnega pogovora: poti do znanja z razumevanjem. [The Power of Learning Conversation: Pathways to Knowledge Through Understanding]. Ljubljana: DZS.

Meglič, A. (2006). Zakaj domovinska vzgoja? [Why Patriotic Education?]. In A. Barle Lakota \& E. Rustja (eds.), Državljanska in domovinska vzgoja [Civic and Patriotic Education] (pp. 66-69). Slovenska Bistrica: Beja.

Ministry of Education, Science and Sport. (2021). Javni razpis za izbor in sofinanciranje programov profesionalnega usposabljanja za šolsko leto 2021/22. [Public Tender for the Selection and Co-financing of Professional Training Programmes for the School Year 2021/22]. https://www.gov.si/zbirke/javne-objave/javni- 
razpis-za-izbor-in-sofinanciranje-programov-profesionalnega-usposabljanjaza-solsko-leto-202122/

Phillips, J. (2008). Teaching History. Developing as a Reflective Secondary Teacher. Los Angeles, London, New Delhi, Singapore: SAGE.

Phillips, R. (2002). Reflective Teaching of History 11-18. London, New York: Continuum.

Potočnik, D. (1997). Vzgoja in pouk zgodovine. [Education and Teaching of History]. Pedagoška obzorja, 12(3-4), pp. 130-133.

Prunk, J. (2006). Državljanska in domovinska vzgoja. [Civic and Patriotic Education]. In A. Barle Lakota \& E. Rustja (eds.), Državljanska in domovinska vzgoja [Civic and Patriotic Education] (pp. 12-16). Slovenska Bistrica: Beja.

Radović, A. \& Pušnik, T. (2011). Analiza stanja na področju državljanske vzgoje v Sloveniji (Analiza institucionalnega okvira teoretskih podlag, učnih načrtov in učbenikov na področju državljanske vzgoje. Projekt Državljan(stvo) v novi dobi). [Analysis of the Situation in the Field of Citizenship Education in Slovenia (Analysis of the Institutional Framework of Theoretical Bases, Curricula and Textbooks in the Field of Citizenship Education. Project Citizenship in the New Age)]. Ljubljana: Ministrstvo za šolstvo in šport.

Razpotnik, J. (2011). Nove teme in pristopi v poučevanju zgodovine v 21. stoletju. [New Topics and Approaches in Teaching History in the 21st Century]. In D. Trškan (ed.), Trojarjev zbornik [The Trojar's Proceeding] (pp. 355-361). Ljubljana: Znanstvena založba Filozofske fakultete.

Repe, B. (2005). Ob desetletnici mature iz zgodovine. [On the Occasion of the Tenth Anniversary of the Matura in History]. Šolska kronika, 14(2), pp. 381-389.

Sardoč, M. (2006). Državljanstvo in državljanska vzgoja. [Citizenship and Citizenship Education]. In A. Barle Lakota \& E. Rustja (eds.), Državljanska in domovinska vzgoja [Civic and Patriotic Education] (pp. 100-107). Slovenska Bistrica: Beja.

Sardoč, M. (2014). Državljanstvo in državljanska enakost. [Citizenship and Civic Equality]. In M. Sardoč (ed.), Osnovni pojmi in dileme državljanske vzgoje [Basic Concepts and Dilemmas of Civic Education] (pp. 11-20). Ljubljana: i2. 
Šepec, B. (2018). Osamosvojitev Slovenije pri zgodovini v 9. razredu osnovnih šol. (Magistrsko delo). [Slovenia's Independence in History in the 9th Grade of Elementary Schools. (Master's Thesis)]. Ljubljana: Filozofska fakulteta Univerze v Ljubljani.

Šeruga, B. (2019). Zgodovina na maturi 2012-2018. [History at Matura 2012-2018]. Zgodovina v šoli, 27(1), pp. 83-93.

Šimenc, M. (Ed.). (2012). Razvoj državljanske vzgoje v Republiki Sloveniji. Konceptualni okvir in razvoj kurikulumov (državljanska vzgoja in etika, družba). [Development of Civic Education in the Republic of Slovenia. Conceptual Framework and Development of Curricula (Civic Education and Ethics, Society)]. Ljubljana: Pedagoški inštitut. https://doi.org/10.32320/978-961-270-146-8

STA. (2019). V srednjih šolah ne bo samostojnega predmeta aktivno državljanstvo. [Active Citizenship will not be an Independent Subject in Secondary Schools]. Dnevnik. https://www.dnevnik.si/1042915487

Štrajn, D. (2006). Identiteta, politika razlike in državljanska vzgoja. [Identity, Politics of Difference and Civic Education]. In A. Barle Lakota \& E. Rustja (eds.), Državljanska in domovinska vzgoja [Civic and Patriotic Education] (pp. 82-88). Slovenska Bistrica: Beja.

Šverc, M. A., Mežan, J., Škrinjar, M., Barle Lakota, A., Rustja, E., Okoliš, S., Švalj, K. \& Filipčič, V. (2007). Slovensko šolstvo, včeraj, danes, jutri. [Slovenian Education System Yesterday, Today, Tomorrow]. Ljubljana: Ministrstvo za šolstvo in šport.

SVIZ. (2017). Državljanska vzgoja in izobraževanje. [Civic Education]. https://www. sviz.si/drzavljanska-vzgoja-in-izobrazevanje/

Taštanoska, T. \& Kresal Sterniša, B. (Eds.). (2013). Državljanska vzgoja v Evropi. [Citizenship Education in Europe]. Ljubljana: Ministrstvo za izobraževanje, znanost in šport. https://www.eurydice.si/publikacije/Drzavljanska-vzgoja-vEvropi-SI.pdf?_t=1560934425

Taštanoska, T. (Ed.). (2013). Nacionalna konferenca Socialna in državljanska odgovornost. Zbornik prispevkov. [National Conference Social and Civic Responsibility. Proceedings]. Ljubljana: Ministrstvo za izobraževanje, znanost in šport. https://www.zrss.si/sidro/files/SIDRO2013-zbornik.pdf 
Tomić, A. (2003). Izbrana poglavja iz didaktike. [Selected Chapters from Didactics]. Ljubljana: Filozofska fakulteta, Center za pedagoško izobraževanje.

Trškan, D. (2008). Lokalna zgodovina - učenje z odkrivanjem. [Local History Learning by Discovery]. Ljubljana: Znanstvenoraziskovalni inštitut Filozofske fakultete.

Trškan, D. (2012). Past into Present: Civic Education and Citizenship in Slovenian History Curricula. International Journal of Historical Learning, Teaching and Research, 11(1) pp. 169-187. https://doi.org/10.18546/HERJ.11.1.12

Trškan, D. (2013). The Influence of the Disintegration of Yugoslavia on Slovenian Curricula for History. International Journal of Historical Learning, Teaching and Research, 11(2), pp. 176-191. https://doi.org/10.18546/HERJ.11.2.14

Trškan, D. (2014). Državljanska vzgoja v učnih načrtih za zgodovino v osnovnih in srednjih šolah. [Civic Education in History Syllabi for Elementary and Secondary Schools]. Pedagoška obzorja, 29(3-4), pp. 3-17.

Trškan, D. (2015). Development of History Teacher Education in Slovenia. In E. Erdmann \& W. Hasberg (eds.), History Teacher Education: Global Interrelations (pp. 91-108). Schwalbach: Wochenschau.

Trškan, D. (2017). The Role of Local History in Elementary and Secondary Schools in Slovenia: An Evaluation of the Centre for School and Outdoor Education = El Papel de la Historia Local en Escuelas Primarias y Secundarias en Eslovenia: La Evaluación del Centro Escolar y Extracurricular. Panta Rei. Revista Digital de Ciencia y Didáctica de la Historia, pp. 123-134. https://doi.org/10.6018/ pantarei/2017/8

Turnšek Hančič, M. (2010). Javnost, globalizacija in izobraževanje. [Public, Globalization and Education]. In J. Pikalo (ed.), Nova državljanstva v dobi globalizacije [New Citizenship in the Age of Globalisation] (pp. 229-251). Ljubljana: Založba Sophia.

Valič Zupan, A. (2006). Izzivi pouka zgodovine, državljanske in domovinske vzgoje. [Challenges of History Lessons, Civic and Patriotic Education]. In A. Barle Lakota \& E. Rustja (eds.), Državljanska in domovinska vzgoja [Civic and Patriotic Education] (pp. 110-116). Slovenska Bistrica: Beja. 
Vodopivec, P. (2006). Zgodovina je imanentno državljanski predmet. [History is an Immanently Civic Subject]. In A. Barle Lakota \& E. Rustja (eds.), Državljanska in domovinska vzgoja [Civic and Patriotic Education] (pp. 38-47). Slovenska Bistrica: Beja.

Zupančič, M. (2021). Zgodovinske vsebine v učbenikih za predmet Domovinska in državljanska kultura ter etika. (Magistrsko delo). [Historical Content in Textbooks for the Subject of Patriotic and Civic Culture and Ethics. (Master's Thesis)]. Ljubljana: Filozofska fakulteta Univerze v Ljubljani.

Zver, M. (2006). Zborniku na pot. [Proceedings on the Way]. In A. Barle Lakota \& E. Rustja (eds.), Državljanska in domovinska vzgoja [Civic and Patriotic Education] (p. 4). Slovenska Bistrica: Beja.

\section{ANALYSED HISTORY CURRICULA}

History Curriculum. Elementary School Education. (2011). https://www.gov.si/ assets/ministrstva/MIZS/Dokumenti/Osnovna-sola/Ucni-nacrti/obvezni/UN_ zgodovina.pdf

History Curriculum. General Secondary School Education. (2008). http://eportal. mss.edus.si/msswww/programi2019/programi/media/pdf/un_gimnazija/un_ zgodovina_280_ur_gimn.pdf

History Knowledge Catalogue. Secondary Technical School Education. (2007). http://eportal.mss.edus.si/msswww/programi2012/programi/Ssi/KZ-IK/kz_ zgodovina_ssi_in_pti_103_126.doc

Social and Natural Sciences Knowledge Catalogue. Short-Term Vocational Education. (2007). http://eportal.mss.edus.si/msswww/programi2019/programi/NPI/KZIK/NPI_KZ_drub_in_nar.doc.

Social Sciences Curriculum. Elementary School Education. (2011). https://www.gov. si/assets/ministrstva/MIZS/Dokumenti/Osnovna-sola/Ucni-nacrti/obvezni/ UN_druzba_OS.pdf

Social Sciences Knowledge Catalogue. Secondary Vocational School Education. (2007). http://eportal.mss.edus.si/msswww/programi2019/programi/SPI/KZIK/spi_kz_dru_132.doc 


\section{ANALYSED HISTORY TEXTBOOKS}

Brodnik, V., Jernejčič, R. \& Zgaga, S. (2009). Zgodovina 1. Učbenik za 1. letnik gimnazije. [History 1. Textbook for the 1st Year of General Secondary School]. Ljubljana: DZS.

Cvirn, J. \& Studen, A. (2010). Zgodovina 3. Učbenik za 3. letnik gimnazije. [History 3. Textbook for the 3rd Year of General Secondary School]. Ljubljana: DZS.

Gabrič, A. \& Režek, M. (2011). Zgodovina 4. Učbenik za 4. letnik gimnazije. [History 4. Textbook for the 4th Year of General Secondary School]. Ljubljana: DZS.

Karlovšek, M. \& Robnik, V. (2014). Zgodovina za srednje strokovno in poklicno tehniško izobraževanje: učbenik. [History for Secondary Vocational and Technical School: A Textbook]. Ljubljana: DZS.

Mirjanić, A., Razpotnik, J., Snoj, D., Verdev, H. \& Zuljan, A. (2016). Raziskujem preteklost 8. Učbenik za zgodovino za 8. razred osnovne šole. [Exploring the Past 8. Textbook for History in the 8th Grade of Elementary School]. Ljubljana: Rokus Klett.

Mlacović, D. \& Urankar, N. (2010). Zgodovina 2. Učbenik za 2. letnik gimnazije. [History 2. Textbook for the 2nd Year of General Secondary School]. Ljubljana: DZS.

Razpotnik, J. \& Snoj, D. (2017). Raziskujem preteklost 9. Učbenik za zgodovino za 9. razred osnovne šole. [Exploring the Past 9. Textbook for History in the 9th Grade of Elementary School]. Ljubljana: Rokus Klett.

Razpotnik, J. \& Snoj, D. (2018). Raziskujem preteklost 7. Učbenik za zgodovino za 7. razred osnovne šole. [Exploring the Past 7. Textbook for History in the 7th Grade of Elementary School]. Ljubljana: Rokus.

Verdev, H. (2016). Raziskujem preteklost 6. Učbenik za zgodovino za 6. razred osnovne šole. [Exploring the Past 6. Textbook for History in the 6th Grade of Elementary School]. Ljubljana: Rokus Klett. 